\title{
Measuring the Effective Role of Public Sector Monitoring and Evaluation in Promoting Good Governance in Uganda: \\ Implications from the Ministry of Local Government \\ OJOK, James | BASHEKA, Benon C.
}

\section{Abstract}

$T^{2}$

he general objective of the study was

to examine effectiveness of the role of public sector monitoring and evaluation in promoting good governance in Uganda, with a focus on Ministry of Local Government. Specifically, the study sought to: examine out how effective role of $M \& E$ accountability, M\&E Management Decision, M\&E Organisational learning in promoting good governance and draw lessons from practice, and provide a recommendation to better inform the implementation strategy of M\&E in the Ministry of Local Government. A case study design was used and both qualitative and quantitative data collection techniques were employed. The respondents comprised of staff of the Ministry of Local Government and Office of the Prime Minister. Quantitative data was analysed using correlation and percentages while qualitative data was analysed using content analysis. The study revealed that M\&E accountability, M\&E management decision and M\&E organisation learning had significant role in promoting good governance in the Ministry of Local Government. It was therefore concluded that M\&E enhanced accountability, management decision and organisation learning and promoted good governance. The study recommended that M\&E should not only be tied to nominal compliance but should support evidence-based decision making. M\&E should be properly institutionalised, funded and located so as to mediate policy process, planning and service delivery.

Keywords: Monitoring and Evaluation, Accountability, Good Governance, Challenges, Decentralisation, Uganda 
Measuring the Effective Role of Public Sector M\&E in Promoting Good Governance in Uganda 411

\section{Introduction}

Monitoring and evaluation (M\&E) has gained ascendency over the past two decades and within this evolution there is an impressive body of literature, a community of practice and even a profession of persons called "evaluators" Scriven (2004: 185). Scriven (1996:183$195)$ for example noted that evaluation was a very young discipline but a very old practice. Conner, Altman, and Jackson (1984:3) reported how evaluation was an established field and was now in its late adolescent years and was at the time making the transition to adulthood. The importance of the monitoring and evaluation (M\&E) function within public administration has been magnified by the growing voice of civil society, which has brought the issues of good governance and more effective public administration to the fore. With the advent of globalization, there are growing pressures on governments and organizations around the world to be more responsive to the demands of internal and external stakeholders for good governance, accountability and transparency, greater development effectiveness, and delivery of tangible results. As demands for greater accountability and real results have increased, there is an attendant need for enhanced result-based monitoring and evaluation of policies, programs, and projects" (Kusek \& Rist, 2004:17-18).

$M \& E$ is therefore seen as supporting a governance function and Cook (2006:12) points out that it encompasses the entire management, operating systems and culture of any institution. He further argues that $M \& E$ promotes governance if supported by a strong government auditing system. It is also meant for improving governmental management (Davis et al, 2006:163-183). The importance given to M\&E by governments of Africa, as part of their process of improving their efficiencies, indicates recognition that change cannot be driven without appropriate tools that generate strategic management information. To express the importance of $M \& E$ as a tool for enhancing good governance, Engel and Carlesson (2002) in Naidoo (2011:29) argued that a sound M\&E should not just improve compliance, it should also enhance the reflective capacity of organisations, whilst simultaneously increasing transparency, accountability and supporting a culture of learning.

The issue of utilisation of evaluation results in the public sector has been a challenge. The factors that affect utilisation of evaluation are contextual (political), technical (methodological) and bureaucratic (psychological) in nature (Mayne, 2000:29). Tuckerman (2007:21-30) assesses these factors in terms of how M\&E contributes to learning and 
reflection, and notes that the mode M\&E is seen as but one tool that supports management by improving the quality of information provided for decision-making.

Theoretically, this study adopted the New Public Management (NPM) model by Rhodes (1997:180) as the theoretical basis for analysing and understanding good governance in the Public Sector. The NPM is arguably one of the most influential theoretical drivers of public sector reforms in Africa. It is often associated with positive, action-oriented phrases like: reinventing government, re-engineering, revitalization of the public service, organizational transformation, total quality management, entrepreneurship, empowerment, downsizing, rightsizing, contracting out, outsourcing, steering rather than rowing, empowering rather than serving and earning rather than spending (Frederickson, 1996 cited in ECA, 2010:20). The NPM is a bundle of particular management practices and techniques borrowed from the private sector. The NPM strives to enhance efficiency, productivity, improved service delivery and accountability. It calls for a reduction in the exclusive reliance on public bureaucracy for service delivery to a system that is advocated for the increased use of the private sector and Non-Governmental Organizations (NGO's) as alternate mechanisms of service delivery(Basheka, 2012:54: Mongkol, 2011:5: 35-43).

Rhodes (1997)cited in Olum (2005:3) argued that the ideas of the NPM are grouped into two strands, namely: those ideas derived from managerialism which emphasises managerial improvements in and restructuring which includes decentralization, dissagregation and downsizing intended to improve the quality of public services, save public expenditure and improve the efficincy of governmental operations. The other strand of NPM ideas are those ideas emanating from new institutional economics which emphasises markets and competitions which include contracting out and adopting a private sector style of management practices. In this second strand NPM is looked at as a set of particular management approaches and techniques which are mainly borrowed from the private sector and applied in the public sector. The New Public Management as argued by Osborne and Gaebler (1992) was meant to make public services competitive, more economic, efficient, effective, value for money oriented, transparent and accountable to the people. Public Sector was viewed as the institutional, structural, and managerial and environmentally influenced mechanism through which governments, by virtue of public trust could administer and deliver services to the citizens (Olum, 2005:3). The NPM has however been criticized based on its major tenants. 
Measuring the Effective Role of Public Sector M\&E in Promoting Good Governance in Uganda 413

Mongkol (2011:35) in a critical review of the NPM contends that the NPM commitment to privatization may be difficult to manage in developing countries because they lack administrative capacity to implement the basic tenets of NPM. Applying market principles into public policy and management in developing countries have proven to be a challenge due to inadequate experience in the operations of markets and lack of basic infrastructure to support market oriented reforms. Government of Uganda undertook Public Sector Reform with the aim of increasing efficiency and effectiveness in the delivery of public service. The significant element of public sector reform was to reform public administration and re-invent government (Mayne and Zapico-Goni, 1997:3-29). It was meant to improve productivity, quality, timeliness, responsiveness, and effectiveness of public agencies and programs, as beneficiaries of public service and as taxpayers.

The importance of Monitoring and evaluation (M\&E) as a management tool for effective governance came to the fore and as it became experience-focused learning for improved service delivery, planning and allocating resources optimally. It clarified, and strengthened awareness and interest in government institutions by focusing on results. The various methods, tools and approaches are clarified from the point of view of purpose, use, advantages, costs, skills, time required and key references. Performance indicators of government operations were measured in terms of inputs, processes, outputs, outcomes and impacts for development projects, programmes, or strategies. The indicators enabled governments to track progress, demonstrable results and take corrective action to improve service delivery and management decision-making by key stakeholders (Olum, 2005:15). Olum (2005:15) argued that the problem of what to measure in order to constitute the criteria that is agreeable in the Public Service delivery remains a complex problem. He also noted that the public sector government officers resent the idea of performance measurement because they have not learnt it properly or lack commitment and training. This resentment led to the adoption of crude performance benchmarks that remain on paper and they end up not being implemented.

Monitoring has been defined by many authors in different ways. Organisation for Economic Cooperation and Development (OECD, 2002:27) defined monitoring as a continuous function that uses systematic collection of data on specific indicators to provide management and main stakeholders of an on-going development intervention with indications of the extent of progress and achievement of objectives. It is also a systematic and objective assessment of an on-going or completed project, programme or policy with 
the aim of determining relevance and fulfilment of objectives, development efficiency, effectiveness, impact and sustainability.

Public Sector M\&E definition comes from the belief that M\&E supports accountability function and is aligned to the field of auditing, compliance and performance management. This means that, M\&E for accountability plays an oversight role and it is a form of civil oversight which comes about when citizens hold government accountable for the use of funds and performance on programmes (Cook 2006:420). Cook (2006:420) further argued that, in accountability oriented M\&E, high levels of scrutiny are expected, and judgement generally made against clear standards and norms that have been established for a range of performance areas. This includes the proper management of budgets, personnel, legal and regulatory compliance with process and procedures and deviation from any of the standards invites censure. Accountability oriented $M \& E$ is seen as supporting governance function which encompasses the entire management, operating systems and culture of the institution.

Although Public Sector M\&E promotes accountability, it's also meant to promote the "learning organisation." This comes at a level of M\&E use and especially when M\&E results are presented. The assumption is that organisations becomes more open and self-reflective when faced with evaluative information, but it is not necessarily the case as operationalizing learning is not easy, given the complex array of protocols and management culture which must be negotiated (Preskill and Russ-Eft, 2005). It has been shown that whilst it is implicit that M\&E should lead to learning and reflection, it may not be the case as the way in which organisations integrate information may be complex and not as casual as suggested in classic M\&E project or programme management terms.

The concept of good governance has widely been used in undertaking development programmes at its worth undertaking a deeper analysis to understand its rationale which happens to emerge from the historical context that saw many governments facing legitimacy and development crisis due to poor governance. According to IFAC Public Sector Committee, Governance in the Public Sector (2001:6) effective governance in the public sector encourages better decision making and the efficient use of resources and strengthens accountability for the stewardship of those resources. Effective governance is characterised by robust scrutiny, which provides important pressures for improving public sector performance and tackling corruption. 
Measuring the Effective Role of Public Sector M\&E in Promoting Good Governance in Uganda 415

The term governance and good governance is being increasingly used within development literature. Governance is referred to as a process of decision-making and the process by which decisions are implemented (UNESCAP (2007:1). It is used in several contexts like corporate governance, international governance, national and local governance. Governance is also defined as a set of values and principles which promote elements of transparency and accountability, good governance, new public management and liberal democracy (Rhodes, 2000 cited in Pierre, 2000:54-90).

Santiso (2001: 7 (1) 1-22) argued that the concept of good governance is relatively new. That it emerged from the World Bank Report (1989:60) on the crisis in Sub Saharan African countries where the capacity, ability and the willing of African Countries to embrace good governance was seen to be a challenge. The report further indicates that good governance system requires that the process of decision-making and public policy formulation is transparent and accountable. It should extend beyond the capacity of public sector rules that create a legitimate, effective and efficient framework to conduct government business. It implies managing public affairs in a transparent, accountable, participatory and equitable manner. It entails effective participation in public policymaking, the prevalence of the rule of law and an independent judiciary, institutional checks and balances through horizontal and vertical separation of power, and effective oversight agencies.

The question of good governance has also been investigated by international bodies like the International Monetary Fund (IMF) and the question of transparency and accountability is scrutinised (Lamdany and Martinez-Diaz, 2009:12). The African Development Bank (2010:5) clarifies the concept of governance by identifying four elements, these being accountability, participation, predictability and transparency. Agencies such as Asian Development Bank, the United Nations Development programme (UNDP), the United Nations Economic and Social Committees for Asia and the Pacific (ESAP) and the World Bank states that good governance is achieved when the following 9 characteristics are displayed; participation, strategic vision, rule of law, transparency, responsiveness, consensus orientation, equity building, effectiveness and efficiency, and accountability. The African Economic Commission (2009) and Transparency International report (2015) indicate that Botswana, Cape Verde and Mauritius among other countries have scored highly in governance and transparency while Republic of Congo, Egypt, Libya, Somali, Central African Republic and Eritrea have done badly. The reports are also 
supported by Mo Ibrahim ranks on good Governance (2015). Opponents of good governance suggest that there is a major difference between the private sector and public sector in that the public sector is all about provision of public goods that is itself not measurable (Musgrave,1970:122). With the above argument, measuring/application of M\&E is practically difficult. However, it's noted that pubic goods can be measured, which Smith and Bratton (2001:453) say that public sector is not special since it uses resources and must account for it. This therefore brings in the idea of M\&E to demonstrate and what level of value added by government. It makes a shift between unaccountable governments and accountable that work for the good of its people. The more fundamental question is what happens when the quality of governance is indeed measured, as would be the case in countries that accept the need for good governance (World Bank, 2006:2). This justifies the use of M\&E in the public sector and answers the question of accountability, transparency and efficiency of governments.

The study therefore seeks to measure how M\&E promotes good governance and the researcher will use the role of M\&E as supporting accountability, management decision, transparency, and organisational learning as variables for measurement against the thrust of good governance such as efficiency, effectiveness, transparency, management of budgets, personnel, legal and regulatory compliance with process and procedures.

\section{The Problem and Research Questions}

Uganda like other African countries has been grappling with the challenge of increasing efficiency and effectiveness in the delivery of services. The fundamental cause of these challenges has been attributed among others to weak M\&E systems (Hauge, 2003: 6). To respond to this challenge government developed and implemented Public Sector M\&E Strategy in the Ministries, Departments and Agencies(MDAs)with the view of enhancing accountability, transparency, management decision, organizational learning and promoting good governance (Public Sector M\&E Policy, 2013:4). However, there has been a contention that a number of MDAs including Ministry of Local Government have not been able to achieve the objectives of the national M\&E arrangement (National Evaluation Study, 2013:55). ACODE in monitoring and assessing performance of Local Governments (ACODE, 2013: VI) established that accountability mechanisms for good governance and public service delivery was either non-existent or malfunctioned. Ministerial Policy Statement of Financial Year 2014/15:50, government performance report 2012/13:125 and Auditor 
Measuring the Effective Role of Public Sector M\&E in Promoting Good Governance in Uganda 417

General's report 2013/2014: Vol 2:80 confirmed the fact that the Ministry still continued to post bad governance results in areas of accountability and budget performance.

A number of studies have been undertaken to understand effectiveness of Public Sector M\&E in Uganda. Ojambo (2012:80) while studying decentralisation in Uganda agreed with the fact that Public Sector M\&E System is not geared towards understanding causality and attribution between the stages of development change while Hauge (2003:13-16) in studying the Development of Monitoring and Evaluation Capacities to Improve Government Performance in Uganda established that the quality of public service delivery is less than desirable and M\&E system has remained overly centred on compliance with government requirements and regulations rather than end-results of policy, program and project efforts. However, none of these focused on the effective role of M\&E in promoting good governance within the Ministry of Local Government. To partially address this gap, this study is being undertaken. The following questions were examined in the study:

RSQ1. To what extent does M\&E Accountability role promote good governance?

RSQ2. Does M\&E Management decision promote good governance?

RSQ3. Does M\&E organisation learning promote good governance?

RSQ4. What are the lessons learnt in the implementation of M\&E Strategy in the Ministry of Local Government?

\section{Conceptual Framework}

The conceptual framework is informed by literature and observation of what is pertained in the field of M\&E and good governance. The study specifically looked at the relationship between the effective role of $M \& E$ and good governance arising from a global sentiment that governments need to adhere to certain norms and standards which seek to improve government practice by ensuring higher levels of transparency and accountability (World Bank 2004). The study adopted the role of M\&E as promoting accountability, enhancing management decisions and promoting organisation learning (Public Sector M\&E Policy, 2013). The study measured the role of M\&E accountability, management decision and organisation learning as an independent variable.

Good governance was a dependant variable and measured in terms of transparency, efficiency, effectiveness in governance. This is adopted from the international framework for good governance in the public sector (IFAC,2014:6) which looks at good governance 
in the public sector as behaving with integrity, demonstrating strong commitment to ethical values, ensuring openness and comprehensive stakeholder engagement, managing risk and performance through robust internal control and strong public financial management, implementing good practices necessary to optimize the achievement of intended outcomes, and developing the of leadership of the entity and individuals.

The study argued that M\&E in pursuit of good governance should lead to discernible changes in the manner in which government is managed, and services experienced by citizens. It should yield the three pronged purpose of improving transparency, accountability and promoting learning. The study further considers that M\&E is a tool to achieve the ideal output while good governance on the other hand is an ideal outcome. The study also considered that M\&E alone does not promote good governance since there are other factors that contribute to good governance but the study focused only on M\&E role accountability, management decision and organisation learning as contributors to good governance. Please refer to figure 1 below:

\section{Figure 1}

IV

Effectiveness of M\&E
DV

Support to Good Governance

Source: (Adapted from OECD DAC Handbook (2011), Naidoo (2011) and modified by the researcher) 
Measuring the Effective Role of Public Sector M\&E in Promoting Good Governance in Uganda 419

\section{LITERATURE REVIEW}

\section{The Role of M\&E Accountability in promoting good governance}

Mulgan (2000:556) defines accountability as acknowledgment and assumption of responsibility for actions, decisions, and policies. He further argued that in governance, accountability expands beyond the basic definition of "being called to account for one's actions". It is described as an account-giving relationship between individuals. He says accountability cannot exist without proper accounting practices; in other words, an absence of accounting means an absence of accountability. A key question that is asked is whether meeting compliance criteria, and hence addressing the accountability dimension, is sufficient for producing the effect or outcome of good governance, or whether the production of good governance requires a more comprehensive application of $M \& E$ (Roper and Petitt, 2002:256-271).

Jabbra and Dwiredi (1989:2) list 8 types of accountability, namely: moral, administrative, political, managerial, market, legal/judicial, constituency relation, and professional. $\mathrm{He}$ indicated that accountability and transparency are some, but not all, of the indicators of good governance. There are others, such as participation, the rule of law and inclusivity, which they point out that even if there is good compliance by government, this is but a partial contribution to good governance, which is a more comprehensive, all-embracing concept. It is possible for the Ministry of Local Government to perform well in terms of mandatory compliance, but still not meet the standards of good governance, as compliance does not equate good governance, which is broader than meeting administrative standards.

\section{The Role of M\&E Management Decision in Promoting Good Governance}

The practice and use of $M \& E$ as part of the decision-making process is more important than formal requirements for $M \& E$. The real product of $M \& E$ is not reports or facts per se, but a higher quality of decision making. M\&E systems augment managerial processes and provide evidence for decision-making (Hauge, 2003:9). The question that should be asked is whether the quality of the M\&E information provided is appropriate and how well it feeds into existing managerial processes. M\&E can never replace good management practices; rather it augments and complements management (Public Service CommissionSouth Africa, 2008:4). Some examples of M\&E used in this context are decisions on 
resource allocation, choices between competing strategies to achieve the same objective, policy decisions, and decisions on programme design and implementation. The accuracy of information and the manner in which it is presented become critical for supporting management in their decision-making processes. M\&E provides the information, in a structured and formalized manner, which allows scrutiny of public service activities at all levels. Tuckerman (2007:21-30) argued that the greater value ascribed to M\&E by decisionmakers, or managers, the greater is the propensity for M\&E to be used in the decisionmaking process and the greater is its potential for promoting good governance.

\section{The Role of M\&E Organisational Learning in Promoting Good Governance}

The M\&E outcome of individual and organisational learning, which is brought about by this form of M\&E is important, as suggested by Roper and Pettit (2002:2). This perspective is embedded in broader discussions about how organisations assimilate and use information, which cannot be taken for granted (Leeuw and Sonnichsen, 2000:93-120). The role of $M \& E$ Organisational learning is the most challenging outcome for $M \& E$, as it presupposes that $M \& E$ results and findings help to create learning organisations. However, translating findings into "learnings" challenges even the most sophisticated of organisations (Public Service Commission of South Africa, 2008:5). Learning has been described as "a continuous dynamic process of investigation where the key elements are experience, knowledge, access and relevance. It requires a culture of inquiry and investigation, rather than one of response and reporting." M\&E produces new knowledge. "Knowledge management means capturing findings, institutionalizing learning, and organizing the wealth of information produced continually by the M\&E system."

In practice, $M \& E$ is one of many streams of information and influences that is used by decision-makers, before decisions are finally made. Tuckerman (2007:21-30) illustrates that learning comes about only when there is communication based on self-reflection and dialogue. Nabris (2002) also shows how M\&E has a particular learning purpose, as failures are explained. Engel and Carlson (2002) view evaluation as opportunities for improving organisational learning.

M\&E is also a research tool to explore what programme design, or solution to societal problems, will work best and why, and what programme design and operational processes will create the best value for money. M\&E should provide the analysis and evidence to do 
Measuring the Effective Role of Public Sector M\&E in Promoting Good Governance in Uganda 421

the trade-offs between various alternative strategies. The information gathered should be translated into analytical, action-oriented reports that facilitate effective decision-making. The focus here is on causes of problems rather than the manifestation of problems (Public Service of South Africa, 2008:6). The literature indicates that the use or disuse of M\&E may not lie only in its availability; its quality may be perceived differently based on perceptions of the M\&E agenda, its perception varies based on whether it is used for accountability, transparency and/or organisational learning, to name but a few. Use of information also depends on the perceived utility, which as Patton (1997:23-25) indicates, is a key factor in determining how it is valued and responded to.

Development of monitoring and evaluation capacities to improve government performance suggest that $M \& E$ is helping to bring greater rationality to public finances and development and providing evidence based foundation for policy, budgeting and operations which are tenets of good governance. Mackey (2006:i) in a study on institutionalisation of M\&E systems to improve Public Sector Management in Africa suggest that support to $M \& E$ systems and capacities in developing counties has an important part of sound governance.

\section{Methodology}

This study adopted correlation mixed-methods research design. This was able to a snapshot of the current problem situation. Correlation study focused on assessing covariation among variables and helped to identify predictive relationships. The study employed a mixed-methods design where both qualitative and quantitative approaches to data collection were used (Mugenda \& Mugenda, 2008). The researcher collected and analysed data, integrated the findings, and drew inferences by using qualitative and quantitative approaches (Teddlie \& Tashakkori, 2009). The population of this study was the staff of Ministry of Local Government and selected staff of Prime Minister's Office.

A sample of 92 was determined by Krejcie \& Morgan (1970) table and individual elements in different categories was determined using different sampling techniques. The objective was to allow for a representative sample, avoid bias and reduce sampling errors. 
422 Africa's Public Service Delivery \& Performance Review

\begin{tabular}{|l|l|c|c|l|}
\hline No & Stratum & Target Popn & Sample Size & Sample Technique \\
\hline 1 & Directors & 1 & 1 & Purposive Sampling \\
\hline 2 & Commissioners & 4 & 4 & Purposive Sampling \\
\hline 3 & Assistant Commissioners & 8 & 4 & Simple Random Sampling \\
\hline 4 & Principal Officers & 20 & 20 & Simple Random Sampling \\
\hline 5 & Senior Officers & 37 & 25 & Simple Random Sampling \\
\hline 6 & Officers & 42 & 30 & Simple Random Sampling \\
\hline 7 & OPM Staff- M\&E Unit & 8 & 8 & Purposive Sampling \\
\hline \multicolumn{2}{|l|}{ TOTAL } & $\mathbf{1 2 0}$ & $\mathbf{9 2}$ & \\
\hline
\end{tabular}

Researcher, sample selection: Krejcie \& Morgan (1970) table.

The Questionnaire was the key method for primary data collection. The questionnaire method was chosen because it had the advantage of eliciting a lot of information within a short time, providing relevant information and being a less costly method (Sekaran, 1992). It is also good for confidentiality purposes (Moser and Kalton, 1979). The selfadministered questionnaires were given to employees to fill. The researcher also obtained some of necessary secondary data information through documentary review. Information was obtained from documents like; The Public Sector Monitoring and Evaluation Policy and guideline, National Development Plan, Local Government reports and publications, OPM reports and Ministerial Policy Statements.

The quantitative analysis was executed using SPSS computer programme. After data collection, a systematic sequence of data preparation (checking, editing and coding), data entry (entering data to SPSS), data processing and analysis, presentation in tables, interpretation of finding and conclusion was done. Data was analysed using regression and correlation to establish the relationships between the independent and dependent variables. Data was presented using tables and descriptive statistics. Pearson correlation test was used to establish relationship between variables and multiple regression coefficient tests was used to establish the effect of independent variables on the dependent variable.

\section{RESULTS}

Out of 92 questionnaires that were distributed to respondents, 85 returned. This represents a response rate of $97.7 \%$. Thus, the findings can, be generalized to the population of the Ministry. The Ministry employed several personalities with different qualifications that 
range from Diploma, Degree and Master's Degree. The result indicates that out of 85 respondents 5(7\%) had a Diploma, 44(51.8\%) had a Degree and 35(41.2\%) had a Master's Degree. Length of service of respondents was considered in the study since it relates to experience and the extent to which the respondent was involved in M\&E processes and implementation. It's also true that the longer one stays in the organization the more information accumulated about the phenomenon. The study indicates that $5(6 \%)$ of the respondents had served for a period of 1-3 years, 20(23.5\%) served for a period of 4-6 years and 60 (70.5\%) served for a period of 7 years and above. This also indicate that $94 \%$ of the respondents are Senior Officers who have clear background in $M \& E$ and are directly involved in M\&E implementation in the Ministry.

The study aimed at examining the effective role of $M \& E$ accountability in promoting good governance in the Ministry of Local Government. The study established the role of M\&E accountability by finding how whether the ministry has an established accountability function, whether accountability standards and procedures are in place and adhered to and whether the ministry prepares plans, budgets, reports as all do contribute to good governance.

Asked whether the ministry has an established accountability function 33(39 percent) respondents strongly agreed, 38(45percent) agreed, 7(8 percent) remained neutral, 6(7\%) agreed and 1(1 percent) strongly agreed. It's therefore evident that the Ministry has function, system and structures. This is confirmed when respondents were asked whether the ministry has acceptable accountability standards, 25(29 percent) of the respondents strongly agreed, 46(54 percent) agreed, 5(6 percent) remained neutral, 3(4 percent) disagreed and $6(7$ percent) strongly disagreed. Similarly, when respondents were asked whether the ministry adhere to established accountability procedures 24 (32 percent) strongly agreed, 43(51 percent) respondents agreed, 9(11 percent) were neural while 4(5 percent) agree and $2(2$ percent) strongly agree. It's also established that these accountability systems procedures and standards are adhered to by the Ministry. The results also indicated that the Ministry prepares and submits financial report as required by government and therefore is rated highly in the government of Uganda annual performance assessment. Since the Ministry has an established accountability function, system, standards and procedures and considering that accountability is an indicator of good governance, it can be concluded that the Ministry is promoting good governance. 
424 Africa's Public Service Delivery \& Performance Review

\begin{tabular}{|c|c|c|c|c|c|c|c|c|c|c|c|}
\hline \multicolumn{12}{|c|}{$\begin{array}{l}\text { Key: SD: Strongly Disagree, D: Disagree, N: Neutral, A: Agree, SA: Strongly Agree } \\
\text { Table 2: Role of M\&E Accountability in promoting good governance }\end{array}$} \\
\hline M\&E Accountability & $\mathbf{M}$ & SD & $\%$ & D & $\%$ & $\mathbf{N}$ & $\%$ & $\mathbf{A}$ & $\%$ & SA & $\%$ \\
\hline $\begin{array}{l}\text { Ministry has put in place acceptable } \\
\text { accountability standards }\end{array}$ & 3.95 & 6 & 7 & 3 & 4 & 5 & 6 & 46 & 54 & 25 & 29 \\
\hline $\begin{array}{l}\text { Ministry adheres to Public Sector } \\
\text { accountability procedures }\end{array}$ & 4.05 & 2 & 2 & 4 & 5 & 9 & 11 & 43 & 51 & 24 & 32 \\
\hline $\begin{array}{l}\text { Ministry is rated high in national } \\
\text { annual government performance } \\
\text { assessment for MDAs }\end{array}$ & 3.76 & 1 & 1 & 8 & 9 & 25 & 29 & 27 & 32 & 24 & 28 \\
\hline $\begin{array}{l}\text { Increased sanctions by accountability } \\
\text { institutions to the Ministry }\end{array}$ & 3.92 & 3 & 4 & 8 & 9 & 14 & 16 & 28 & 33 & 32 & 38 \\
\hline $\begin{array}{l}\text { Ministry prepares and submits financial } \\
\text { reports to government as provided for } \\
\text { in the Public Finance Act }\end{array}$ & 4.22 & 2 & 2 & 1 & 1 & 9 & 11 & 37 & 44 & 36 & 42 \\
\hline $\begin{array}{l}\text { There is an established accountability } \\
\text { function in the Ministry }\end{array}$ & 4.13 & 1 & 1 & 6 & 7 & 7 & 8 & 38 & 45 & 33 & 39 \\
\hline $\begin{array}{l}\text { Ministry adheres to the approved } \\
\text { budgets }\end{array}$ & 3.85 & 2 & 2 & 6 & 7 & 18 & 21 & 36 & 42 & 23 & 27 \\
\hline Aggregate mean & 3.55 & & & & & & & & & & \\
\hline
\end{tabular}

Sources: Field Data: 2016: Uganda

Table 3: Correlation of M\&E Accountability and Good Governance

\begin{tabular}{|ll|r|r|}
\hline & & M_E_Accountability & M_E_Good_Governance \\
\hline M_E_accountability & Pearson & 1 & $.706^{* *}$ \\
& Correlation & & \\
& Sig. (2-tailed) & & .000 \\
& $\mathrm{~N}$ & 85 & 85 \\
\hline M_E_Good_governance & Pearson & $.706^{* *}$ & 1 \\
& Correlation & .000 & \\
& Sig. (2-tailed) & 85 & 85 \\
$\mathrm{~N}$ & & & \\
\hline
\end{tabular}

${ }^{* *}$ Correlation is significant at the 0.01 level (2-tailed). 
The result indicates $P=0.706$. This means that there is a strong positive relationship between M\&E Accountability and Good Governance. This means that changes in one variable are strongly correlated with changes in the second variable. From the table the level of significance is 0.000 . It can be concluded that there is a statistically significant correlation between M\&E Accountability and Good Governance. That means, increases or decreases in one variable do significantly relate to increases or decreases in your second variable.

The second objective of the study was to assess the role of M\&E Management Decision promoting good governance. M\&E role of being part of decision-making process is important. M\&E systems augment managerial processes and provide evidence for decision-making. The real product of $M \& E$ is not reports or facts per se, but a higher quality of decision making. The study assessed the role of M\&E Management decision in promoting good governance.

\begin{tabular}{|c|c|c|c|c|c|c|c|c|c|c|c|}
\hline \multicolumn{12}{|c|}{$\begin{array}{l}\text { Key: SD: Strongly Disagree, D: Disagree, N: Neutral, A: Agree, SA: Strongly Agree } \\
\text { Table 4: Role of M\&E Management Decision in promoting good governance }\end{array}$} \\
\hline M\&E Management Decision & M & SD & $\%$ & D & $\%$ & $\mathbf{N}$ & $\%$ & A & $\%$ & SA & $\%$ \\
\hline $\begin{array}{l}\text { Information Management } \\
\text { contributes to Transparency and } \\
\text { Accountability }\end{array}$ & 4.02 & 2 & 2 & 7 & 8 & 10 & 12 & 34 & 40 & 32 & 38 \\
\hline $\begin{array}{l}\text { Management Decision based on } \\
\text { prevailing legislations and } \\
\text { monitoring reports }\end{array}$ & 3.80 & 3 & 4 & 6 & 7 & 15 & 18 & 42 & 49 & 19 & 22 \\
\hline $\begin{array}{l}\text { Ministry takes proactive stance } \\
\text { when it comes to engaging with } \\
\text { external stakeholders }\end{array}$ & 3.72 & 2 & 2 & 9 & 11 & 16 & 19 & 42 & 49 & 16 & 19 \\
\hline $\begin{array}{l}\text { M\&E information used for } \\
\text { accountability purposes }\end{array}$ & 3.66 & 2 & 2 & 11 & 9 & 14 & 9 & 45 & 48 & 13 & 31 \\
\hline $\begin{array}{l}\text { I feel part of management process } \\
\text { and I contribute to good } \\
\text { governance }\end{array}$ & 3.95 & 2 & 2 & 8 & 9 & 8 & 9 & 41 & 48 & 26 & 31 \\
\hline $\begin{array}{l}\text { Ministry Policy Statement in place } \\
\text { and articulates governance } \\
\text { decisions }\end{array}$ & 4.42 & 1 & 1 & 2 & 2 & 4 & 5 & 31 & 36 & 47 & 55 \\
\hline Aggregate mean & 3.93 & & & & & & & & & & \\
\hline
\end{tabular}

Source: Field Data: 2016: Uganda 
From the data in Table 4, 32 (38 percent) of the respondents strongly agreed that information management in the ministry has contributed to transparency and accountability which are the hallmarks of good governance, 34(40 percent) agreed with the notion, 10(12 percent) of the respondents remained neutral while 7 (8 percent) agreed and 2(2 percent) strongly agreed.

When asked whether management decision based on prevailing legislations and monitoring reports the results indicate that 19 (22 percent) strongly agreed while $42(49$ percent) agreed, 15 (18 percent) neither agreed nor disagreed, 6 (7 percent) agreed and 3(4 percent). It can be noted that 61 (71.7 percent) of the respondents agreed that management decisions in the ministry is based on legislations and monitoring reports which is an indication of promotion of good governance. The same result is seen when respondents were asked about whether the ministry takes proactive stance when it comes to engaging with external stakeholders, whether M\&E information used for accountability purposes, whether staff are part of management process and whether ministry Policy Statement in place and articulates governance decisions. On average, $46 \%$ of respondent agreed with the role of M\&E Management decision in promoting good governance in the Ministry of Local Government, however 2\% strongly disagree, and the results shows that $13 \%$ could neither agree nor disagree with role of M\&E Management decision in promoting good governance in the Ministry of Local Government.

Table: 5: Correlation of M\&E Management Decision and Good Governance

\begin{tabular}{|ll|r|r|}
\hline & & $\begin{array}{r}\text { M_E_Management } \\
\text { Decision }\end{array}$ & \multicolumn{2}{|c|}{$\begin{array}{c}\text { M_E_Good } \\
\text { Governance }\end{array}$} \\
\hline M_E_Management Decision & Pearson Correlation & 1 & $.592^{* *}$ \\
& Sig. (2-tailed) & .000 \\
& $\mathrm{~N}$ & 85 & 85 \\
\hline M_E_Good Governance & Pearson Correlation & $.592^{* *}$ & 1 \\
& Sig. (2-tailed) & .000 & 85 \\
& $\mathrm{~N}$ & 85 & \\
& & & \\
\end{tabular}

** Correlation is significant at the 0.01 level (2-tailed).

The result indicates $P=0.592$. This means that there is a moderate positive relationship between M\&E Management Decision and Good Governance. This means that changes in one variable are strongly correlated with changes in the second variable. From the table 
the level of significance is 0.000 . It can be concluded that there is a statistically significant correlation between M\&E Management Decision and Good Governance. That means, increases or decreases in one variable do significantly relate to increases or decreases in your second variable. The third objective was to assess the role of M\&E organizational learning in promoting good governance. Monitoring and evaluation provides information and facts that, when accepted and internalized, become knowledge that promotes learning. The study assessed the role of M\&E organizational learning in promoting good governance and the results are as in table 6 below:

Key: SD: Strongly Disagree, D: Disagree, N: Neutral, A: Agree, SA: Strongly Agree Table 6: M\&E Organisational learning in promoting good governance

\begin{tabular}{|l|l|l|l|l|l|l|l|l|l|l|l|}
\hline M\&E Organisational learning & M & SD & $\%$ & D & $\%$ & N & $\%$ & A & $\%$ & SA & $\%$ \\
\hline $\begin{array}{l}\text { Staff understand the role of } \\
\text { M\&E }\end{array}$ & 3.44 & & & & & & & & & & \\
\hline $\begin{array}{l}\text { Staff always involved in } \\
\text { monitoring and supervision }\end{array}$ & 3.64 & 2 & 2 & 15 & 18 & 14 & 16 & 35 & 41 & 19 & 22 \\
\hline $\begin{array}{l}\text { M\&E information useful for } \\
\text { learning purposes }\end{array}$ & 3.72 & 2 & 2 & 12 & 14 & 15 & 18 & 35 & 41 & 21 & 25 \\
\hline $\begin{array}{l}\text { M\&E taken as a critical } \\
\text { management tool }\end{array}$ & 3.67 & 5 & 6 & 11 & 13 & 14 & 16 & 32 & 38 & 23 & 27 \\
\hline $\begin{array}{l}\text { M\&E implemented produces } \\
\text { useful management report }\end{array}$ & 3.87 & 5 & 6 & 8 & 9 & 28 & 33 & 30 & 35 & 14 & 16 \\
\hline M\&E adds value to work & 3.86 & 3 & 4 & 10 & 12 & 10 & 12 & 35 & 41 & 27 & 32 \\
\hline $\begin{array}{l}\text { M\&E component sufficiently } \\
\text { integrated into the Ministry } \\
\text { Institutional arrangement }\end{array}$ & 3.48 & 4 & 5 & 15 & 18 & 15 & 18 & 38 & 45 & 13 & 15 \\
\hline Aggregate Mean & 3.67 & & & & & & & & & & \\
\hline
\end{tabular}

Source: Field Data: 2016: Uganda

Table 6 provides responses on the role of organization learning in promoting good governance in the Ministry of Local Government. The result indicates that 46 (54.1 percent) of the respondents generally agree that they understand the role of $M \& E$, 22(25.9 percent) remained neutral while 17 (20 percent) of the respondents disagreed. Although 54.1 percent agreed that they understand the role of $M \& E$ an almost equal number of 
respondents either disagreed or remained neutral. This indicate that the level of understanding seems to be relatively low. When asked whether they are involved in $M \& E_{\text {, }}$ 54(63.5 percent) of the respondents agreed, 14(16.5 percent) neutral and 17(20 percent) disagreed. It must be noted that the level of involvement in increases the level of knowledge. It is therefore true that the level of involvement in M\&E contributed to the level of understanding of M\&E in the Ministry.

Asked whether M\&E information is useful for learning processes, 56(65.9 percent) of the respondents agreed that $M \& E$ information is useful for learning purposes.15(17.6 percent) could not tell while 14(16.5 percent) disagreed. It can be concluded that while staff are involved in $M \& E$ activities they gain knowledge and M\&E enhances learning of staff. The result also indicated that M\&E is taken as a critical management tool and adds value to work. Respondents also agreed that M\&E component is sufficiently integrated into the Ministry Institutional arrangement.

Table: 7: Correlation of M\&E Organization Learning and Good Governance

\begin{tabular}{|c|c|c|c|}
\hline & & M_E_Organisation Learning & M_E_Good Governance \\
\hline $\begin{array}{l}\text { M_E_organisation_ } \\
\text { Learning }\end{array}$ & $\begin{array}{l}\text { Pearson } \\
\text { Correlation } \\
\text { Sig. (2-tailed) } \\
\text { N }\end{array}$ & $\begin{array}{r}1 \\
85\end{array}$ & $\begin{array}{r}.549^{* *} \\
.000 \\
85\end{array}$ \\
\hline $\begin{array}{l}\text { M_E_Good_ } \\
\text { Governance }\end{array}$ & $\begin{array}{l}\text { Pearson } \\
\text { Correlation } \\
\text { Sig. (2-tailed) } \\
\mathrm{N}\end{array}$ & $\begin{array}{r}.549^{* *} \\
.000 \\
85\end{array}$ & $\begin{array}{r}1 \\
85\end{array}$ \\
\hline
\end{tabular}

${ }^{* *}$ Correlation is significant at the 0.01 level (2-tailed).

The result indicates $P=0.549$. This means that there is a moderate positive relationship between M\&E organization learning and Good Governance. This means that changes in one variable are strongly correlated with changes in the second variable. From the table the level of significance is 0.000 . It can be concluded that there is a statistically significant correlation between M\&E Management Decision and Good Governance. That means, 
increases or decreases in one variable do significantly relate to increases or decreases in your second variable.

\section{Good Governance in the Ministry of Local Government}

The study attempts to examine the concept of good governance and its elements, such participation, predictability and transparency and how they relate to $M \& E$ roles of enhancing accountability, management decisions and promoting organizational learning. The results are as in table 8 below:

\section{Key: SD: Strongly Disagree, D: Disagree, N: Neutral, A: Agree, SA: Strongly Agree}

Table 8: Good Governance

\begin{tabular}{|c|c|c|c|c|c|c|c|c|c|c|c|}
\hline M\&E Good Governance & M & SD & $\%$ & D & $\%$ & $\mathbf{N}$ & $\%$ & $\mathbf{A}$ & $\%$ & SA & $\%$ \\
\hline $\begin{array}{l}\text { Strong commitment to } \\
\text { integrity, ethical values and the } \\
\text { rule of law }\end{array}$ & 3.92 & 2 & 2 & 7 & 8 & 12 & 14 & 39 & 46 & 25 & 29 \\
\hline $\begin{array}{l}\text { Ministry has open and } \\
\text { comprehensive stakeholder } \\
\text { engagement }\end{array}$ & 3.79 & 1 & 1 & 9 & 11 & 16 & 19 & 40 & 47 & 19 & 22 \\
\hline $\begin{array}{l}\text { Ministry has robust internal } \\
\text { control and strong public } \\
\text { financial management system }\end{array}$ & 3.88 & 2 & 2 & 8 & 9 & 11 & 13 & 41 & 48 & 23 & 27 \\
\hline $\begin{array}{l}\text { Ministry invest in developing } \\
\text { capacity of entity, leadership } \\
\text { and staff }\end{array}$ & 3.85 & 4 & 5 & 4 & 5 & 15 & 18 & 40 & 47 & 22 & 26 \\
\hline $\begin{array}{l}\text { Ministry implementing good } \\
\text { practices in transparency and } \\
\text { reporting to deliver effective } \\
\text { accountability }\end{array}$ & 4.01 & 2 & 2 & 8 & 9 & 9 & 11 & 34 & 40 & 32 & 38 \\
\hline $\begin{array}{l}\text { Ministry determines } \\
\text { interventions necessary to } \\
\text { optimize achievement of } \\
\text { intended outcomes }\end{array}$ & 3.91 & 1 & 1 & 7 & 8 & 12 & 14 & 44 & 52 & 21 & 25 \\
\hline Aggregate Mean & 3.89 & & & & & & & & & & \\
\hline
\end{tabular}

Source: Field Data: 2016: Uganda 
Respondents were asked whether the ministry is strongly commitment to integrity, ethical values and the rule of law; whether the ministry is open and comprehensive in stakeholder's engagement; whether the ministry invest in developing capacity of entity, leadership and staff; whether the ministry is implementing good practices in transparency and reporting to deliver effective accountability, and whether the ministry determines interventions necessary to optimize achievement of intended outcomes. Result from Table 4.11, shows an average 47 percent of respondent who agree with good governance, Transparency and commitment in the ministry of local government. However, 2 percent strongly disagree and the results show that 15 percent could neither agree nor disagree with good governance, transparency and commitment in the ministry of local government. Other breakdown is as follows, 8 percent disagrees, 28 percent strongly agrees with good governance, Transparency and commitment in the ministry of local government. This high percentage shows that the respondent had trust in good governance, Transparency and commitment in the ministry of local government.

\section{Challenges in M\&E Implementation}

The study examined the challenges faced by the Ministry in an attempt to implement to implement the Public Sector Monitoring and Evaluation. The results are as in table 9:

\begin{tabular}{|c|c|c|c|c|c|c|c|c|c|c|c|}
\hline \multicolumn{12}{|c|}{$\begin{array}{l}\text { Key: SD: Strongly Disagree, D: Disagree, N: Neutral, A: Agree, SA: Strongly Agree } \\
\text { Table 9: Challenges in the Implementation of } M \& E\end{array}$} \\
\hline $\begin{array}{l}\text { Challenges of M\&E } \\
\text { Implementation }\end{array}$ & $\mathbf{M}$ & SD & $\%$ & D & $\%$ & $\mathbf{N}$ & $\%$ & A & $\%$ & SA & $\%$ \\
\hline $\begin{array}{l}\text { Ministry has adequate } \\
\text { Human Resource Capacity in } \\
\text { M\&E }\end{array}$ & 3.35 & 2 & 2 & 23 & 27 & 18 & 21 & 27 & 32 & 15 & 18 \\
\hline $\begin{array}{l}\text { M\&E is not viewed as a } \\
\text { priority }\end{array}$ & 2.67 & 14 & 16 & 34 & 40 & 12 & 14 & 16 & 19 & 9 & 11 \\
\hline $\begin{array}{l}\text { Ministry has appropriate M\&E } \\
\text { implementation strategy }\end{array}$ & 3.33 & 2 & 2 & 14 & 16 & 33 & 39 & 26 & 31 & 10 & 12 \\
\hline $\begin{array}{l}\text { M\&E system is cascaded and } \\
\text { properly understood by staff }\end{array}$ & 3.14 & 4 & 5 & 25 & 29 & 22 & 26 & 23 & 27 & 11 & 13 \\
\hline $\begin{array}{l}\text { There is identified priority } \\
\text { areas for } M \& E\end{array}$ & 3.36 & 3 & 4 & 18 & 21 & 22 & 26 & 29 & 34 & 13 & 15 \\
\hline
\end{tabular}


Measuring the Effective Role of Public Sector M\&E in Promoting Good Governance in Uganda 431

\begin{tabular}{|c|c|c|c|c|c|c|c|c|c|c|c|}
\hline $\begin{array}{l}\text { There is lack of an effective } \\
\text { communication strategy to } \\
\text { inform policy development } \\
\text { and planning }\end{array}$ & 2.98 & 9 & 11 & 28 & 33 & 14 & 16 & 24 & 28 & 10 & 12 \\
\hline Aggregate Mean & 3.14 & & & & & & & & & & \\
\hline
\end{tabular}

Source: Field Data: Uganda: 2016

In establishing the challenges, the Ministry is facing in the implementation of Public Sector M\&E respondents were asked whether the ministry has adequate Human Resource Capacity in $M \& E$, whether ministry has appropriate $M \& E$ implementation strategy, whether M\&E system is cascaded and properly understood by staff and whether there is identified priority areas for M\&E. It can be seen from the results that an average of $28 \%$ of the participants agree and an average of $28 \%$ disagrees with challenges the ministry is facing in implementation of Public Sector Monitoring and Evaluation, from result above shows that an average of $24 \%$ could neither agree nor disagree with challenges ministry is facing in implementation of Public Sector Monitoring and Evaluation. When 3 staff of the Office of the Prime Minister where asked about the challenges MDAs are facing in the implementation of the Public Sector M\&E the staff confirmed that challenges such as lack of training, inappropriate M\&E implementation strategies, inadequate HR capacity, lack of funding for $M \& E$ and in some MDAs $M \& E$ is not viewed as a priority. This finding relates to the results from table 9 above.

Table 10: Correlation between Good Governance and Challenges in implementation Correlations

\begin{tabular}{|ll|r|r|}
\hline & \multicolumn{1}{|c|}{$\begin{array}{c}\text { M\&E Good } \\
\text { governance }\end{array}$} & \multicolumn{2}{|c|}{ M\&E challenges } \\
\hline M\&E Good & Pearson Correlation & 1 & $.332^{* *}$ \\
governance & Sig. (2-tailed) & & .002 \\
& $\mathrm{~N}$ & 85 & 85 \\
\hline M\&E challenges & Pearson Correlation & $.332^{* *}$ & 1 \\
& Sig. (2-tailed) & .002 & 85 \\
& $\mathrm{~N}$ & 85 & \\
& & & \\
& & &
\end{tabular}

${ }^{* *}$ Correlation is significant at the 0.01 level (2-tailed).

For the above figure, there was a weak positive correlation of 0.332; this weak Positive correlation however this results may mean that M\&E Challenges and Good Governance 
move in different directions. As M\&E challenges increases, Good Governance may decrease.

As seen from the correlation, coefficients, these relationships are statistically significant, meaning that challenges that affect implementation of M\&E do affect governance in the Ministry of Local Government.

\section{SUMMARY OF FINDINGS}

The findings indicate that there is a strong positive relationship between $M \& E$ Accountability and good governance and the relationship was proved statistically significant. The study agreed that for accountability to promote good governance, an institution has to have a strong accountability function, system, standards and procedures and this should be strongly institutionalized in the functioning of the Ministry. Strong accountability systems, standards and procedures should not only be established but should be operationalized and adhered to. Continuous assessments have to be done to ensure that the system is functioning and achieving the purpose for which it has been established. The study also reveals that the ministry adheres to the principles of mandatory M\&E. This is adherence to established accountability requirements such as submission of policy statements, budget proposals and accountability.

The role of M\&E management decision-making in promoting good governance was statistically significant, indicating that M\&E management decision-making plays a significant role. The study reveals that information management in the Ministry has contributed to transparency and accountability which are the hallmarks of good governance. It also indicates that management decisions are based on the prevailing legislations and monitoring reports, which is an indication of promotion of good governance. The same result shows that M\&E information used for accountability purposes and staff are part of the management process. Although a number of respondents either remained neutral while others disagreed, the role of $M \& E$ management decision-making in promoting good governance in the Ministry of Local Government is evident.

The role of M\&E organizational learning in promoting good governance was proved statistically significant. The relation between M\&E and good governance was positively related. This implies that M\&E organizational learning influences good governance. This is further confirmed by responses that indicate a general understanding of the role of $M \& E$ by staff in the Ministry. This shows that M\&E was cascaded, although a few disagree. The 
Measuring the Effective Role of Public Sector M\&E in Promoting Good Governance in Uganda 433

disagreement may have arisen because of lack of continuous training, number trained in $M \& E$ and level of involvement in M\&E activities. This agrees with the results which indicate that staff were involved and involvement increased the level of knowledge. It is therefore true that the level of involvement in M\&E contributed to the level of understanding of $M \& E$ in the Ministry. The results also indicated that M\&E is taken as a critical management tool and adds value to work. Respondents also agreed that the M\&E component is sufficiently integrated into the Ministry's institutional arrangement.

\section{DISCUSSION OF RESULTS}

The fundamental role of Public Sector M\&E is to enhance accountability and increase efficiency and effectiveness in the way government works. The study revealed that the Ministry has established accountability systems, standards and procedures shown in table 2 indicating aggregate mean of 3.55 and a correlation of 0.706 . This is supported by Mulgan (2000:556) who argued that in governance, accountability expands beyond the basic definition of "being called to account for one's actions." He said accountability cannot exist without proper accounting practices; in other words, an absence of accounting means an absence of accountability. However, a fundamental question is whether meeting compliance criteria is sufficient for producing the effect or outcome of good governance. The Ministry requires a more comprehensive application of M\&E to be able to achieve good governance. The Ministry must re-enforce the level of compliance to regulatory requirements related to accountability for it to achieve good governance.

The finding of the study indicated that M\&E Management decision has a positive though moderate relationship with good governance. This is shown in Table 10 which indicated an aggregate mean of 3.93 and a correlation coefficient 5.92. This means that M\&E management decision is significant in promoting good governance. This relates to how information received from $M \& E$ contributes in making management decisions. It also relates to the practice and use of $M \& E$ as part of the decision-making process. These findings agree with Hauge (2003) who argued that M\&E systems should augment managerial processes and provide evidence for decision-making. The question that should be asked is whether the quality of the M\&E information provided is appropriate and how well it feeds into existing managerial processes. The extent to which decisions are made based on prevailing legislations and whether decisions made translates to good governance is an issue of contention. Tuckerman (2007:21) argued that the greater value 
ascribed to $M \& E$ by decision-makers or managers, the greater is the propensity for $M \& E$ to be used in the decision-making process and the greater is its potential for promoting good governance. It's therefore important to note that, if decisions are based on $M \& E$ results and are translated to ministry systems and practices then M\&E would have an effective role in promoting good governance.

The research examined the extent to which M\&E organization learning contribute to good governance. It is presupposed that $M \& E$ results and findings help to create learning organization. The result indicates that the role of $M \& E$ in promoting organization learning and promoting good governance is moderate but positive with a correlation coefficient of 0.549 and aggregate mean of 3.67. The study shows that M\&E findings and results do contribute to organization learning but the extent to which the ministry is taking advantage of M\&E results and finding to promote learning, how M\&E information is useful for learning purposes and the extent to which M\&E is integrated in the Ministry still remains a challenge. This is supported by Public Service Commission of South Africa (2008:4) who argued that translating findings into "learnings" is the most sophisticated of organizations. $\mathrm{He}$ further argued that knowledge management means capturing findings, institutionalizing learning, and organizing the wealth of information produced continually by the M\&E system.

The Ministry should ensure $M \& E$ is well located in the policy process. M\&E should mediate policy process by producing valid evidence for policy decisions thereby ensuring greater objectivity and transparency. There is need for stronger coordination to ensure that M\&E helps guide ministry's actions toward greater effectiveness. The potential exists for a more integrated and effective $M \& E$ programme in the Ministry. The ministry should allocate greater resources for M\&E function, and ensure recognition and integration of M\&E into all levels of management.

\section{CONCLUSIONS AND IMPLICATIONS}

The study examined the effectiveness of the role of public sector monitoring and evaluation in promoting good governance in Uganda, with a focus on the Ministry of Local Government. Specifically, the study examined the effective role of M\&E accountability, M\&E management decision, M\&E organisational learning in promoting good governance. The employed a case study design and both qualitative and quantitative data collection techniques were employed. The respondents comprised staff of the Ministry of Local 
Measuring the Effective Role of Public Sector M\&E in Promoting Good Governance in Uganda 435

Government and Office of the Prime Minister. The study targeted 92 participants but 85 returned the questionnaires, indicating a response rate of $97.7 \%$. A purposive sample technique was used to select directors, commissioners, principal officers and staff of OPM; while simple random technique was used to select senior officers. Quantitative data was analysed using correlation and percentages while qualitative data was analysed using content analysis.

The study established that an effective Public Sector M\&E should enhance accountability. Effective accountability system, standards and procedures is a necessary but sufficient precondition for promotion of good governance. It also established that an increase in the level of accountability should led to a significant increase in the level of good governance. Where there are commitments in ensuring accountability, chances for good governance to flourish is high. M\&E should play a role in supporting an effective management decision since $M \& E$ provide information that supports decision making. An effective decision arising from $M \& E$ information is expected to improve governance.

$M \& E$ findings and results are expected to cause organization learning (Roper and Pettit, 2002) When M\&E information is collected, analyzed and transformed to a decision, an organization is able to learn and do thing better (Schick (2001: 43). It's true that if this happens, organizational skills and knowledge will increase and this will enhance efficiency and effectiveness which in turn will support good governance (Naidoo: 2011). The study indicates that $M \& E$ is often tied to nominal compliance with reporting requirements, rather than responding to the underlying performance revealed by M\&E. The ministry should not tie $M \& E$ to nominal compliance but should broadly support evidence-based decisionmaking and $M \& E$ data should be used to inform choices in the different stages of planning and public service delivery.

\section{List of References}

- Advocates Coalition for Development and Environment (ACODE), 2013/14 Public Service Delivery and Accountability Report Series No.21, 2014.

- African Development Bank (2010) Elements of Governance. Good Governance Practices. http://adb.org/Governance/gov_elements.asp. 
- Auditor General Annual Report (2013/2014), w.w.w.oag.go.ug/volume1/-annual-report-ofthe-Auditor General, Kampala Uganda.

- Basheka, B. C. 2012. The Paradigms of Public Administration Re-Examined: A Reflection Journal of California, Sage.

- Carlsson, C and Engel, P. 2002. Enhancing learning through evaluation approaches, dilemma some possible ways forward. Background paper presented at the 2002 EES Conferences, Seville, October 10-12, 2003 ECDPM.

- Conner, Altman and Jackson, 1984, cited in Lance, H (2007) Online Journal of workforce education and development Vol 11, Issue 4-Fall 2007, The Historical Development of Programme Evaluation: Exploring the past and present, East Illinois University, Page 3.

- Cook, T.P. 2006. Collaborative Action Research within Development Evaluation, Learning to see or the Road to Myopia, Evaluation 12(4).

- Davies, P, Newcomer. K, and Soydan, H. 2006. Government as structural context for evaluation, in Shaw I.F, Greene J.C and MarK, M.M (eds). The SAGE handbook of Evaluation, London, Sage Publishers. Pp.163-183.

- Engel, P.G.H. and Carlesson, C. 2002. Enhancing learning through evaluation: Approaches, dilemmas and some possible ways forward, Paper commissioned by the Ministry of Foreign Affairs, Directorate-General for Development Cooperation, the Netherlands, to be presented at the 2002 European Evaluation Society Conference, Seville; October 10-12, 2002.

- Frederickson, G. 1996. Comparing the Reinventing Government Movement with the New Public Administration. Public Adm. Rev. 53(3):214-29, ECA (2010). Innovations and Best Practices in Public Sector Reforms: The Case of Civil Service in Ghana, Kenya, Nigeria and South Africa.

- Government Annual Performance Report (2013/14), OPM, Kampala, Uganda

- Hauge, A. 2003. The Development of Monitoring and Evaluation Capacities to Improve Government Performance in Uganda. Operations Evaluation Department ECD working paper No. 10. Washington D.C, The World Bank.

- IFAC - Public Sector Committee Report (2001) Governance in the Public Sector, Washington 6

- Jabbra, J.G and Dwivedi, O.P. 1989. Public Service Accountability. A Comparative Perspective, Kumarian Press, Hartford, C.T ISBN 0-7857-7581-4 
- Krejcie, R. V., \& Morgan, D. W. 1970. Determining Sample Size for Research Activities. Education and Psychological Measurement, pp.607-610.

- Kusek, J.Z. and Rist, R.C. 2004. Ten Steps to a Results-based Monitoring and Evaluation Systems: A Handbook for Development Practitioners. Washington, D.C.: The World Bank. pp xi, 17-20

- Lamdany, P \& Martinez-Diaz, 2009. Studies of IMF Governance, A compendium, IMF Publications Series, Washington, w.w.w.ieo-imf.org

- Leeuw, F., Rist, R., \& Sonnichsen, R. (Eds.), (1994) Can governments learn? Comparative Perspectives on evaluation and organizational learning New Brunswick, NJ: Transaction the Canadian Journal of Program Evaluation Vol. 21 No. 3 PP, 93-120

- Mackay, K. 2006. Institutionalisation of Monitoring and Evaluation Systems to Improve Public Sector Management. Independent Evaluation Group. Series 15, the World Bank.

- Musgrave, Richard A. 1970. Buchanan on the Demand and Supply of Public Goods. Finanz Archive / Public Finance Analysis, 29 (1): 122-127.

- Mayne, J. 2000. Utilising evaluation in organisations: The balancing act, In Leeuw, F.L., Rist, R.C. and Sonnichsen, R.C (eds) 2000. Can Governments learn? Comparative Perspectives on Evaluation and Organisation Learning. USA: Transaction Publishers. pp 17-43.

- Mayne, J., \& Zapico-Goni, E. 1997. "Effective performance monitoring: A necessary condition for Public Sector Reform." In monitoring performance in the public sector, eds. Mayne, J and Zapico-Goni, E. New Jersey, Transaction Publishers.

- Ministerial Policy Statement Financial Year 2014/2015, Ministry of Local Government Kampala Uganda, pp 1-50

- Mongkol, K. 2011. The critical review of New Public Management Model and its criticisms, Research Journal of Business management 5(1):35-43, 2011

- Moser, C.A \&Kalton, G, 1979. Survey methods in Social Investigation, Heinemann, Educational Books, Ltd, London

- Mugenda, O. M., \& Mugenda, A. G. 2008. Research methods, quantitative and qualitative approaches. Nairobi: ACTS Press.

- Mulgan, R. 2002. Accountability Issues in the New Model of Governance, Discussion paper No.91 of April 2002. 
- Nabris, K. 2002. Civil Society Empowerment Palestine Academic Society for the Study of International Affairs. http://www.passia.org

- Naidoo. I.A. 2011. The role of monitoring and evaluation in promoting good governance in South Africa: A case study of the Department of Social Development, PHD thesis, University of Johannesburg. pp.213.

- National Policy for Public Sector Monitoring and Evaluation (2013), Kampala Uganda, pp 136 Ojambo. 2012. Decentralization in Africa, A critical review of Uganda's experience Potchefstroom Electronic Law Journal, Vol 15, No 2.2012

- Olum, Y. 2005. Public Service Reform in Uganda (1989-2002): A Critical Appraisal, Makerere University, p. 3 .

- Organization for Economic Corporation and Development (OECD 2002). Glossary of Key terms in Evaluation and results Based management. P 27.

- Osborne, D and Gaebler, T. 1992. Re-inventing Government: How the Entrepreneurial spirit is Transforming the Public Sector, Addison-Wesley Publication Co, New York: p. 427

- Patton, M.Q. 2004. The roots of utilisation focused evaluation, In Alkin, M.C (ed) 2004, Evaluation Roots, Tracing Theories, views and influences, USA, SAGE.

- $\quad$ Patton. M.Q. 1997. Utilisation-focused Evaluation. CA, Thousand Oaks: Sage, pp. 23-25

- $\quad$ Preskill \& Russ-Eft. 2005. Building Evaluation Capacity. 72 activities for teaching and training, California, Sage.

- Public Service Commission-South Africa (2008), Basic concepts in Monitoring and Evaluation, Custodian of good governance, The Public Service Commission, p. 4

- Rhodes, R. A. W. 1997. Understanding Governance. Policy Networks, governance, Reflexivity and Accountability cited in Olum, Y (2005) Public Service Reform in Uganda (1989-2002): A Critical Appraisal, w.w.w.unpan1.un.org/intradoc/groups/.

- Rhodes, R.A.W. 2000. Governance and public administration, In Pierre, J. (ed) Debating Governance New York, Oxford University Press

- Roper, L. and Petitt, J. 2002. Development and learning organisation; an introduction. Development in practice, pp.258-271.

- Santiso, C. 2001. Good governance and aid effectiveness. The World Bank and conditionality Public Policy Review. 7 (1) 1-22 
- Scriven, M. 1996. Reflections, In Alkin, M.C. (Ed) Evaluation Roots, Tracing Theories, Views and Influences. USA: SAGE. pp. 183-195.

- Schick, A. 2001. Getting performance measures to measure up, In Forsythe, D.W. (Ed) Quicker, Better, Cheaper: Managing Performance in American Government. New York: The Rockefellers Institute Press. pp. 39-60.

- Sekaran, U. 2003. Research Methods of Business: A skill building Approach, 4th ed. John Wiley \& sons Inc.

- Smith, D.C and Bratton, W.J. 2001. Performance Management in New York City. Compstat and the revolution in policy management cited Naidoo. A (2010), A case study of the Department of Social Development, PHD thesis, University of Johannesburg.

- Teddle \& Tashakkori, 1998. Combining qualitative and quantitative approaches. Applied Social Research Series. Vol 46

- Tuckermann, B.C. 2007. Challenges and key success factors to integrating learning and change in Monitoring and evaluation of development projects: Case study of an urban agriculture project in Eastern Cuba, Knowledge Management for Development Journal, $4(1): 21-30$

- United Nations Economic and Social Commission for Asia and the Pacific (UNESCAP) http://www.unescap.org/sites/default/files/good-governance.pdf

- World Bank Report, (2006) A decade of measuring the quality of governance, Governance Matters, World Bank, Washington.

- World Bank, (1989) Sub-Saharan Africa: From Crisis to Sustainable Development, Washington, World Bank

- World Bank. (2010) The Worldwide Governance Indicators Project. http://info.worldbank.org/governance/wgi/index.asp.

- World Bank, (2004), Public Sector Governance, http://www1.worldbank.org/publicsector/index.cfm>

AUTHORS' CONTACT:

\begin{tabular}{|c|c|}
\begin{tabular}{c|c} 
OJOK, James \\
Bganda Technology \& Management University \\
Email: ojokalaljames@yahoo.co.uk
\end{tabular} & $\begin{array}{l}\text { Uganda Technology \& Management University } \\
\text { Email: bbasheka@yahoo.co.uk }\end{array}$ \\
\hline
\end{tabular}

